\title{
制振木質軸組架構の振動台実験と終局耐震挙動 \\ SHAKING TABLE TEST AND ULTIMATE SEISMIC BEHAVIOR \\ ON PASSIVE CONTROLLED WOODEN FRAME
}

\author{
伊藤拓海，黒川久瑠美**, 点 東 航 $^{* * *}$, 南雲隆司 ${ }^{* * * *}$, 平田春彦***** \\ Takumi ITO, Kurumi KUROKAWA, Dong Hand WU, \\ Takashi NAGUMO and Haruhiko HIRATA
}

\begin{abstract}
A new passive control system called Scaling Frame was suggested by authors. In this study, the ultimate seismic response behavior and response mitigation effect of SF are investigated by shaking table tests on one-story wooden framed test specimen. Herein, four test specimens of various structural types are prepared with SF and structural plywood installed. From the test results, the mitigation effect of SF is confirmed. And also, SF can retain the stable hysteresis behavior even if the structural plywood is collapsed. Furthermore, the seismic vibration characteristics and resistant mechanism are investigated by response analysis.
\end{abstract}

\author{
Keywords : Seismic passive control system, Wooden frame, Shaking table test, Restoring force \\ characteristics, Seismic response analysis, Equivalent viscous damping factor \\ 制振, 木質軸組架構, 振動台実験, 復元力特性, 地震応答解析, 等価粘性減衰定数
}

1. はじめに

近年, 地震による戸建木造住宅の甚大な被害を受けて, 制振化, 免震化に向けた研究開発が行われている. また, 住宅メーカーを中 心にして, 様々な制振・免震装置が開発・商品化され, 実用化され ている.これに対して,著者らは制振構造の研究開発を行っており, 本稿は木質架構用の制振構造を対象とし，その弾塑性応答挙動と制 振効果について検討したものである.

ここで，制振構造の特性や特徴を分類すると，Table 1のように大 別される ${ }^{1}$. 寸なわち, 抵抗系 (履歴型, 粘性型, 摩擦型), 力学機 構（軸抵抗型，せん断抵抗型，曲げ抵抗型）, 材料 (金属系, オイル 系，など）を軸として分類できる。また，適用対象の建物規模や構 造種別はTable 2のように整理できる。これらに対して，本研究で提 案する制振構造は，Scaling Frame（以降，SF）と呼ばれており，金 属系材料による曲げ抵抗型の履歴ダンパーに分類される.

著者らが提案している制振構造（SF構造）は，Fig.1のように，制 振化する構面の柱梁フレームに対し, 対角線上に矩形の金属系材料

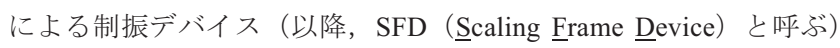
を配置し，斜材で接合して構成する．ここで，ラーメン構造は柱梁
部材の曲げ抵抗機構, ブレース構造は筋交いの軸抵抗機構, 耐力壁 構造は面材のせん断抵抗機構に分類される.これに対し, SF構造は, 柱梁フレームとSFDフレームの相似関係により，水平力を受けた際 にSFDの変形が進行しやすく, その塑性曲げ挙動によりエネルギー 吸収能力を発揮する.力学原理の詳細は本稿2章で説明する.

本制振構造に関する著者らの先行研究として，木質軸組架構に対 する静的水平載荷実験による検討 ${ }^{2}$ を実施している，著者らは，こ の制振構造の木造住宅や鉄骨造への適用を想定し，様々な実験的・ 解析的検討 ${ }^{3-7}$ )進めている。 Fig 2のように, SFDの形状や重㸚合わ せ方を変えることで, 高い力学性能を持つSF構造の実現を目指して いる，すなわち，本研究で提案する制振構造は，木造並びに中低層 鉄骨造を対象とし，対象範囲をTable 1,2のように想定している。

本論文では，この制振構造を木質軸組架構に搭載した場合，動的 応答下での耐震性能や終局動的挙動を解明するため，振動台実験を 実施し, 実証的な検討を行う。さらに, 実験結果に基づき, 復元力 特性や振動特性を明らかにするとともに，振動台実験に対して時刻 歴応答解析を行い，実験結果の追跡精度や，実験結果に対する解析 的検討を行い，終局耐震性能や制振効果を明らかにする.

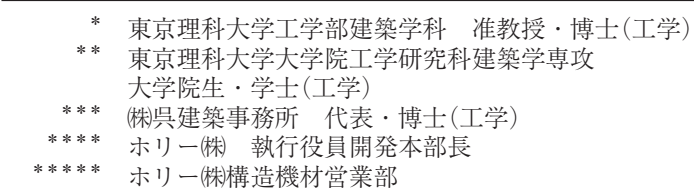

* 東京理科大学工学部建築学科 准教授 · 博士 (工学) 大学院生. 学十(科学

**** ホリー㧣) 執行役員開登本部長 ホリー(株構造機材営業部

Assoc. Prof., Dept. of Archi., Faculty of Eng., Tokyo Univ. of Science, Dr.Eng. Grad. Stud., Dept. of Archi., Graduate School of Eng., Tokyo Univ. of Science, B.Eng.

President, WU Building Office Corp., Dr.Eng.

Development Division General Manager, Hory Corporation

Structure Equipment Sales Department, Hory Corpotation 
Table 1 Summary of passive control devices ${ }^{1)}$

\begin{tabular}{|c|c|c|l|}
\hline System & \multicolumn{2}{|c|}{ Mechanics } & \multicolumn{1}{c|}{ Member } \\
\hline Passive & $\begin{array}{c}\text { Energy } \\
\text { Dissipation }\end{array}$ & $\begin{array}{c}\text { Viscous } \\
\text { Damping }\end{array}$ & $\begin{array}{l}\text { Viscous Damping Member } \\
\text { (Viscosity, Oil, Viscoelasticity) }\end{array}$ \\
\cline { 3 - 4 } & & $\begin{array}{c}\text { Plasticity } \\
\text { Hysteresis }\end{array}$ & $\begin{array}{l}\text { Plasticity Hysteresis Member } \\
\text { (Steel, Lead, Friction) }\end{array}$ \\
\cline { 2 - 4 } & \multicolumn{2}{|c|}{ Added Mass } & Tuned Mass Damper, etc \\
\hline
\end{tabular}

Table 2 Application of vibration control devices on buildings

\begin{tabular}{|c|c|c|c|c|c|c|}
\hline \multirow[b]{2}{*}{ Style } & \multirow[t]{2}{*}{ Scale } & & Low & Middle & High & Tall \\
\hline & & & $10 \mathrm{~F}$ & 15 & \multicolumn{2}{|c|}{$25 \mathrm{~F}$} \\
\hline \multirow{3}{*}{ Steel } & SRS & & & & & \\
\hline & VCS & & SF & SF & & \\
\hline & SIS & & & & & \\
\hline \multirow{3}{*}{$\mathrm{R} / \mathrm{C}$} & SRS & & & & & \\
\hline & VCS & & & & & \\
\hline & SIS & & & & & \\
\hline \multirow{3}{*}{ Wooden } & SRS & & & & & \\
\hline & VCS & SF & & & & \\
\hline & SIS & & & & & \\
\hline
\end{tabular}

SRS: Seismic Resistant Structure, VCS: Vibration Control Structure, SIS:

Seismic Isolated Structure

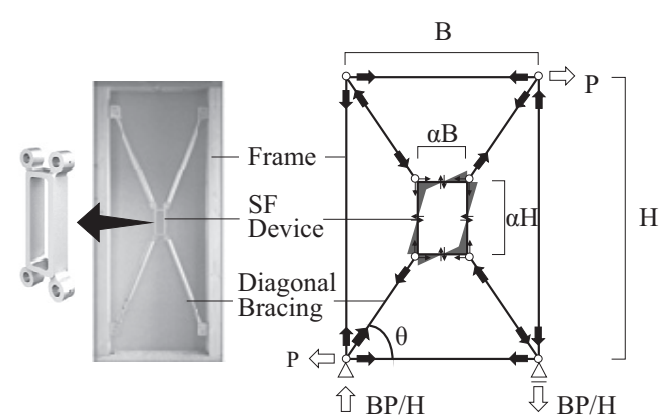

Fig. 1 Conceptual Diagram of SF Structure
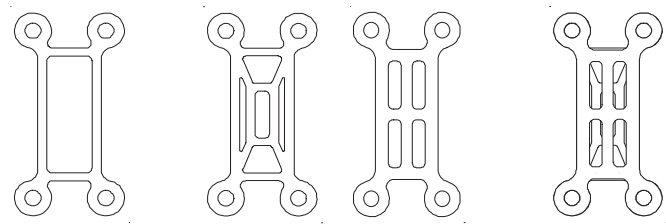

Basic shape

Different shape

Hybrid

Fig. 2 Various type and combination of SFD

\section{Scaling Frame 構造の概要}

SF 構造は, Fig.1 に示すように, 柱梁フレームに比例して縮小し た矩形の SFD（四隅剛接, または一体成型）を, 柱梁フレームの対 角線の交点に設け, 斜材で連結する構造である. 木質建物において 実用化されている SF 構造のディテールを Fig 3 に示寸. なお, 柱梁 フレームと SFDの比率を縮小率と呼ぶ.

$\mathrm{SF}$ 構造の水平剛性と耐力は, SFD の曲げ耐荷機構に基づいて力学 的に求めることができ, 縮小率に反比例する（補遺 A に示す）。ま た, SFD が対角線上に配置されることで, 柱梁フレームの変形に対 して SFD の変形が進行しや寸くなり, 斜材の圧縮変形が過度になら ないことが，実験的に明らかにされている4)（補遺 B に示す）．

SFD の要素試験結果 ${ }^{4}$ の一例を Fig.4 に示寸. 同図のように, 縮小

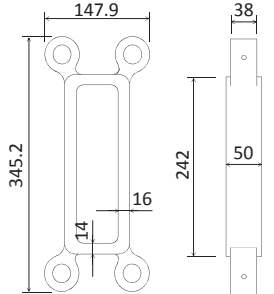

(a) SFD

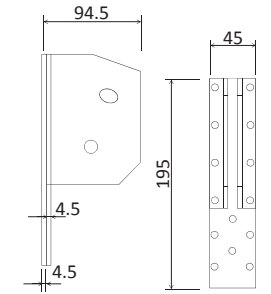

(b) Joint metal

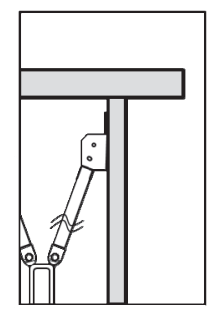

(c) Joint point
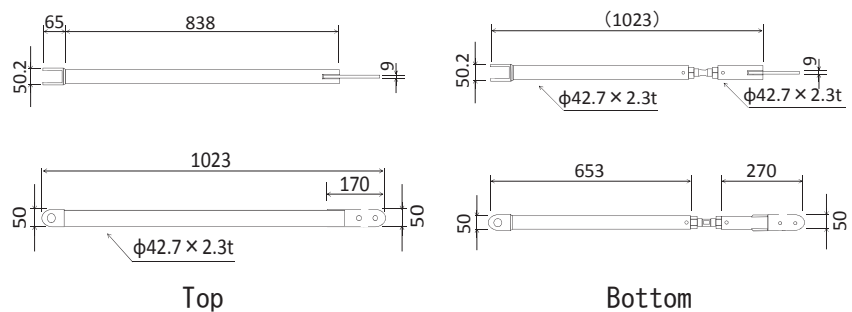

(d) Diagonal bracing

Fig. 3 Detail of SF Structure

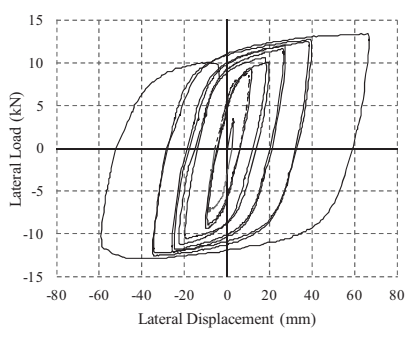

(a) reduction ratio $8.5 \%$

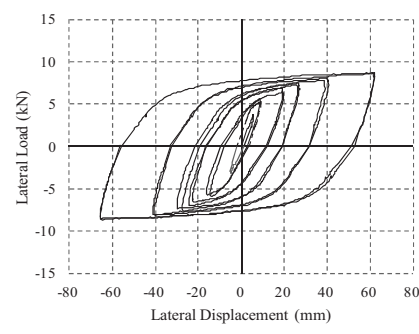

(b) reduction ratio $11.5 \%$
Fig. 4 Load-displacement Relation Curve of SFD')

率が小さいほど剛性, 耐力が大きくなり, 紡錘型の履歴挙動を示す ことが確認できる.

\section{3. 振動台実験の概要}

\section{1 実験計画と目的}

試験体の設計にあたり, 試験体の寸法と構成, 耐力は, 実用化さ れている SF 構造を有する木質建物の仕様と設計条件に基づいてい る. 寸なわち, 試験体の寸法と構成は, 1 スパン $0.91 \mathrm{~m}$, ねじれの ないように SF 構造を対象配置する.

また，振動台実験で入力する加振波のプログラムに関しては，近 年の地震状況を勘案して次のように設定した。遭遇する可能性の高 い中地震あるいは前震，本震として巨大地震，ならびに余震（中〜 大程度までの 2 段階）を想定した. さらに, 終局耐震状態を把握し, 建物の継続使用性も検証するための終局レベルの入力波を設定した.

以上の方針に対して，実験計画を以下に詳述する.

\section{2 試験体の構成と使用材料}

Fig.5に試験体図を示寸. 本研究の試験体は, 平面 $1,950 \times 2730 \mathrm{~mm}$, 階高 $2,790 \mathrm{~mm}$ の 1 層木質軸組架構とした。軸組はスギ製材の土台

$(105 \mathrm{~mm} \times 150 \mathrm{~mm}) ，$ 柱・床梁 $(105 \times 105 \mathrm{~mm}) ，$ ベイマツ製材の 梁・胴差 $(105 \times 180 \mathrm{~mm})$ で構成し, 水平構面には剛床となるよう に構造用合板（24mm厚 N75@150）を用いた。 また，柱と土台の接 合には，SFDを有する木質建物用に実用化されているホールダウン 
金物を用いている.なお, このアンカーボルトは, 埋込み深さによ って短期許容引張耐力が定められており, 本試験体では $36.1 \mathrm{kN}$ とな る. また, 加振前のボルトは手締めとし, 加振中の締め直しは行っ ていない, なお，振動台と試験体のボルトレイアウトの関係から， Fig.5のように, 桁行構面の内側2本の柱は, 振動台とホールダウン 金物を直接接合していない. しかし，実験中の斜材軸力の実験デー 夕に相違がなく, 実験で観察された挙動から, 接合条件の違いによ る影響はなく,十分な反力が得られていたものと考えられる.なお, ホールダウン金物の許容引張耐力相当の荷重に対し, 土台は十分な 曲げ耐力を有していることを, 計算により確認している.

$\mathrm{SFD}$ はアルミニウム $(\mathrm{A} 1050 \mathrm{P})$ より切削加工し, 斜材は円形鋼管 （STK400）を用いた. SFDと斜材はピン接合とし，斜材と軸組は端 部金物で接合した．SFDの縮小率は $8.5 \%$ とした．以上の使用材料の 機械的性質をTable 3に示寸.

試験体は，1）構造用合板4枚からなるPLY4試験体，2) SFを4構面 有するSF4 試験体，3）構造用合板2構面とSF2枚からなるPLY+SF試 験体, また参考として4) 軸組のみのFrame試験体, 以上4体を用意し た（Table 4）. 合板とSFDは, Fig.5 (a)のY1, Y3 通りに設置した. 試験体の積載重量は, 振動台の積載重量制限（4ton）を考慮し, 3.3tonの鋼板を試験体屋上に固定して設置した.

以上の試験体に関して, 試験体設計時における固有周期, 壁倍率, ベースシア係数を Table 4 に示す. なお, 固有周期は, 上述の錘と試 験体の設計時に想定した試験体重量を合わせた総重量 3.5ton を用い, 汎用構造解析ソフト SNAPより求めた.

\section{3 加振プログラム}

入力加振波を Table 5 に示す. 遭遇する可能性の高い中地震として, 建築センター波レベル 1 とレベル 2(以下, BCJ-L1, BCJ-L2), 本震 に相当する巨大地震として 1995 年兵庫県南部地震において神戸海 洋気象台で観測された波の NS 成分の原波（以下，JMA-Kobe）を採 用した。 さらに，余震として BCJ-L2, BCJ-L1 を採用した。 その後, 終局耐震状態と継続使用性の検証のため, JMA-Kobe を再度採用し た. なお，損傷状況や振動特性の変化を検出する目的で, これらの 地震波の入力前に, パルスとホワイトノイズ（1～10Hz まで段階的 に変化）を入力した，ここで，各入力波の名前において，末尾の○ の数值は, 同じ入力波の回数を表している.

なお，試験体に甚大な損傷が発生し，倒壊の恐れが高くなった際 には, 予定の加振を中止した。 具体的な経過として, PLY4 試験体 では, JMA-Kobe(2)の加振により合板が大きく損傷し, JMA-Kobe(3)

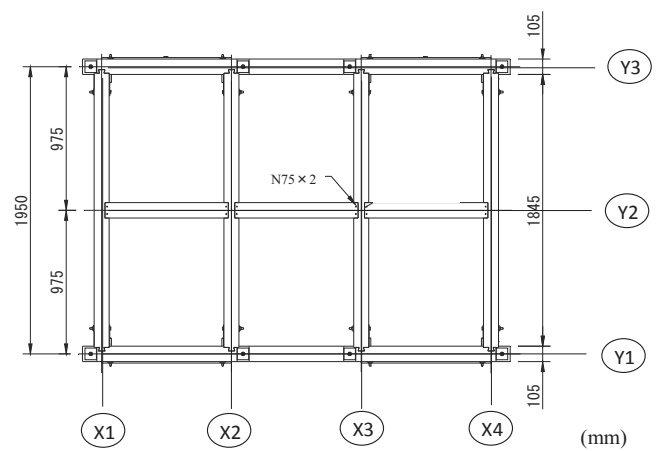

Fig. 5 (a) Floor Plan of Test Specimen (unit: mm)

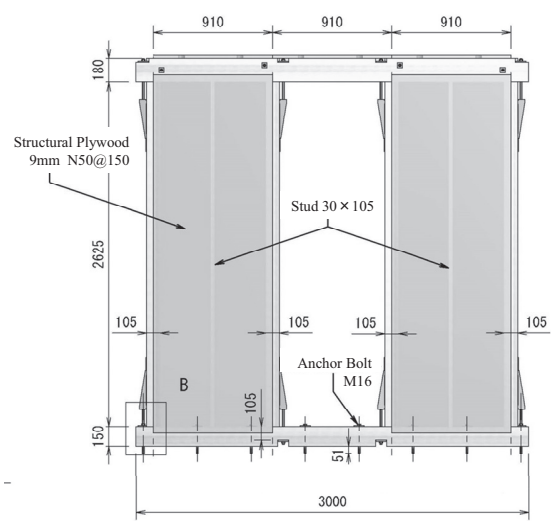

(b-1) PLY4

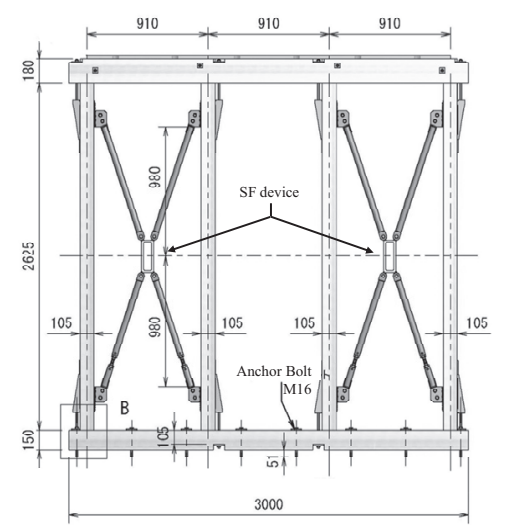

(b-2) SF4

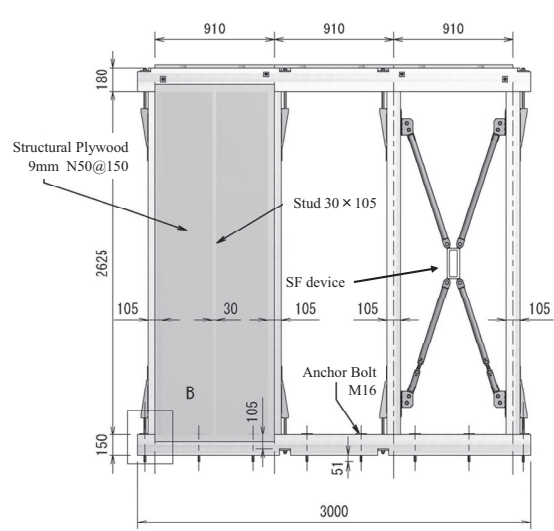

(b-3) PLY+SF

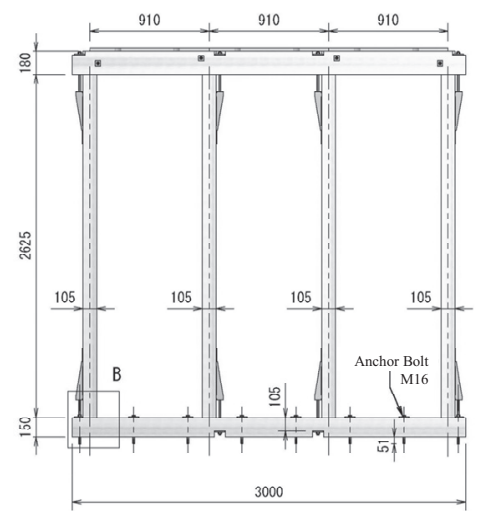

(b-4) Frame

Fig. 5 (b) Elevation of Test Specimen (unit: mm) 
Table 3 Mechanical Properties of Members

\begin{tabular}{|c|c|c|c|c|}
\hline Grade & Yield strength & Tensile strength & Elongation & Parts \\
\hline A1050P & - & $115 \mathrm{~N} / \mathrm{mm}^{2}$ & $25 \%$ & SFD \\
\hline STK400 & $366 \mathrm{~N} / \mathrm{mm}^{2}$ & $437 \mathrm{~N} / \mathrm{mm}^{2}$ & $33 \%$ & diagonal \\
\hline
\end{tabular}

Table 4 Summary of Test Specimen

\begin{tabular}{|c|c|c|c|c|c|c|}
\hline Specimen & $\begin{array}{c}\text { Mass } \\
\text { [ton] }\end{array}$ & Plywood & SF & $\begin{array}{c}\text { Period } \\
{[\mathrm{s}]}\end{array}$ & $\begin{array}{c}\text { Wall } \\
\text { magnification }\end{array}$ & $\begin{array}{c}\text { Base shear } \\
\text { coefficient }\end{array}$ \\
\hline \hline PLY4 & 3.79 & 4 & - & 0.280 & 2.5 & 0.48 \\
\hline SF4 & 3.81 & - & 4 & 0.218 & 2.6 & 0.50 \\
\hline PLY+SF & 3.80 & 2 & 2 & 0.243 & $2.5,2.6$ & 0.49 \\
\hline FRAME & 3.72 & - & - & - & 0 & - \\
\hline
\end{tabular}

の加振は中止した. Frame 試験体は, BCJ-L1(2)により軸組の損傷が 甚大となったため, JMA-Kobe(1)-(3)の入力を中止した. 以上, 実際 の加振記録を Table 5 に示す.

\section{4 計測計画}

計測図を Fig.6 に示す. 振動台の床面と試験体屋上に加速度計を 設置し, 基礎と屋上の加速度を測定した。巻込み式変位計を計測フ レームに取り付け, 梁に設置し, 土台との相対水平変位を計測した. SFD の復元力を求める目的で, 斜材にひずみゲージを添付した.

\section{4. 実験結果と考察}

\section{1 実験経過と観察された損傷状況}

振動台実験では，1）構造用合板と釘の損傷，2) SFDの曲げ降伏， 3) ホールダウン金物の損傷, 4) 軸組接合部の損傷, 以上 4 つの損 傷が観察された. 観察された損傷状況の一例を Fig.7, ならびに損傷 発生, その後の損傷状況の記録を Table 5 に示す.

PLY4 試験体において, JMA-Kobe(1)入力時に合板が大きく損傷し, その後 BCJ-L2 で合板の損傷が進行し, 軸組接合部に損傷が確認さ れた。これに対し, SF4 試験体では, BCJ-L1(1)入力時から SFDの塑 性変形が確認され, 全加振波入力後も軸組に損傷は見られなかった。 PLY+SF 試験体では, SF4 試験体と同様に, BCJ-L1(1)入力時から SFD の塑性変形が生じた.JMA-Kobe(1)入力時に合板の損傷が生じるもの の, PLY4 試験体の JMA-Kobe(1)入力時と比較し, 損傷が小さく抑え られていた. その後, SFDの損傷・合板の損傷は進行したが, 軸組 の損傷は確認されなかった. また, 合板の損傷については, JMA-Kobe (3)加振後も, PLY4 試験体の JMA-Kobe(1)入力時と同程度であった.

\section{2 実験結果}

実験結果について, ホワイトノイズ入力における実験結果より, 固有周期を求め, 結果を Fig.8 に示す. なお, PLY4 試験体の BCJ-L1 (1)入力前のホワイトノイズ入力では, 計測データに不備があり, 結 果が得られなかった. 水平荷重一層間変形角関係の履歴曲線と累積 変形曲線について, 一例として JMA-Kobe(1), BCJ-L2, JMA-Kobe (2)を Fig.9, 10 にそれぞれ示す。応答振幅に対する最大層間変形角の 推移を Fig.11, 入力エネルギーと SFD の塑性吸収エネルギーの関係 をFig.12 に示す。なお，SFDの塑性吸収エネルギーは，斜材のひず みゲージから求めた斜材軸力から, SFDによる水平力を求めて算出 している.さらに, 文献 ${ }^{8-10)}$ に基づき, 等価粘性減衰定数を算出し, ここでは一例としJMA-Kobe(1), JMA-Kobe(2)の結果をFig.13に示す.

\subsection{1 振動特性}

Fig.8の結果より，BCJ-L1(1)など入力が小さく試験体が損傷する
Table 5 Vibration Program and Collapse Mode

\begin{tabular}{|l|l|l|l|l|}
\hline Step & Frame & PLY4 & SF4 & PLY+SF \\
\hline 1.BCJ-L1(1) & 4 & & 1 & 1 \\
\hline 2.BCJ-L1(2) & 4 & & 1 & 1 \\
\hline 3.JMA-Kobe(1) & - & 2 & 1 & $1,2,3$ \\
\hline 4. BCJ-L2 & 4 & 2,4 & 1 & $1,2,3$ \\
\hline 5.BCJ-L1(3) & - & 2,4 & 1 & $1,2,3$ \\
\hline 6.JMA-Kobe(2) & - & 2,4 & 1 & $1,2,3$ \\
\hline 7.JMA-Kobe(3) & - & - & 1 & $1,2,3$ \\
\hline
\end{tabular}

-: not complied with, WN: white noise, 1: SF yield, 2: damage of nail, 3: damage of hole down hardware, 4: damage of framework

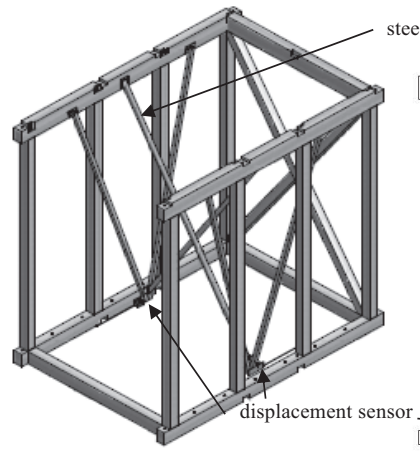

axonometric

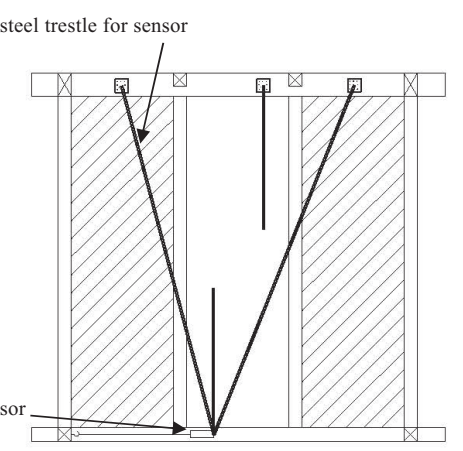

elevation (a) measurement of displacement

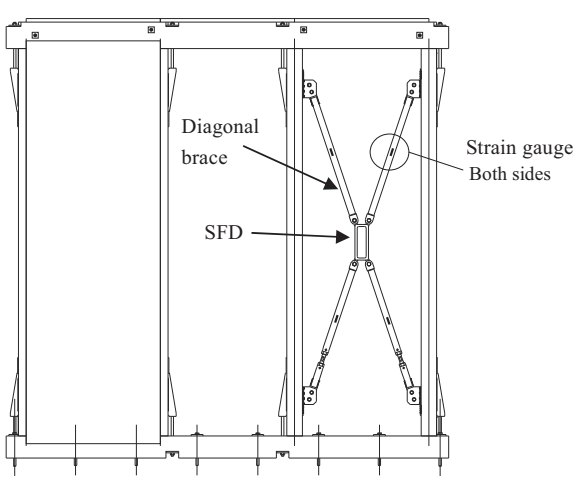

(b) Iayout of strain gauge on SFD and diagonal member

Fig. 6 Setup and Location of Sensors

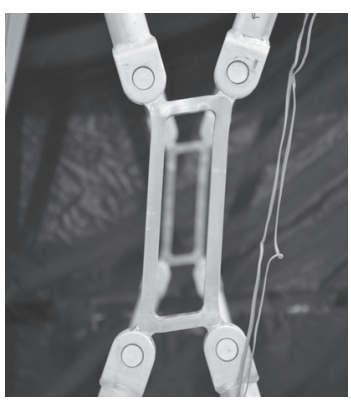

(a) SFD yielding

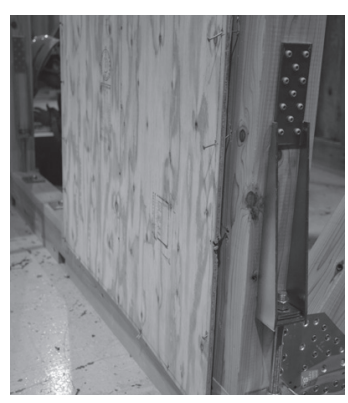

(b) Damage of nail
Fig. 7 Collapse Mode during Shaking Table Tests

前の固有周期は, Table 4 に示す試験体設計時の固有周期と概ね一致 していることが確認できる。また，各試験体の損傷が進むと固有周 期が大きくなることが確認できる. 
PLY4試験体について, JMA-Kobe(1)で合板が損傷した後, Frame 試験体の固有周期に近くなっていることが確認できる.このことか ら, 合板が抵抗要素として機能しなくなったことが考えられる.

SFD を有する試験体では, JMA-Kobe(1)入力後から終局レベル (JMA-Kobe(2), (3)）に至るまで, 固有周期が大幅に上昇することな く0.3〜0.4 秒を示している. このことから, SFD が抵抗要素として 機能していたことが考えられる.

\subsection{2 履歴曲線と復元力特性}

ここでは, Figs.9,10より各試験体の復元力特性について検討する.

Figs.9 (a),10(a)の結果より，PLY4 試験体では，JMA-Kobe11)におい てスリップ挙動が確認できる。これにより, Fig.11と合わせて, SFD を有する試験体と比較して応答変位が大きくなる様子が確認できる.

Figs9，10 の結果より，SFD を有する試験体では，SF4 試験体は安 定した紡錘型の挙動を示し, PLY+SF 試験体では合板の損傷で現れ るスリップ挙動が抑えられ，紡錘型に近い履歴挙動が確認できる.
なお，PLY+SF 試験体では，ピンチング挙動も確認できる。また， SF4 試験体の結果において，わずかにスリップが見られるが，これ はSFDと斜材のボルトクリアランスに起因したものと考えられ，い

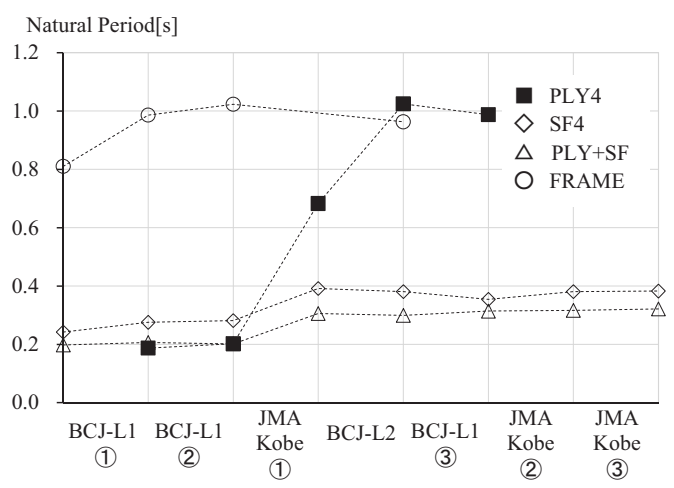

Fig. 8 Transition of Natural Period

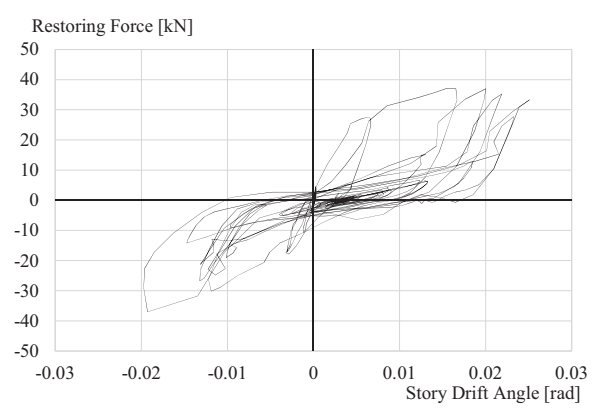

PLY4-specimen

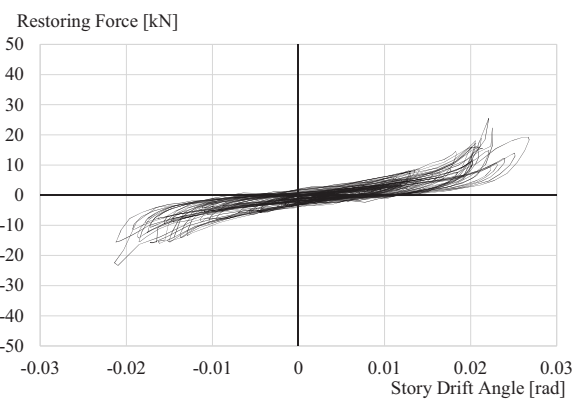

PLY4-specimen

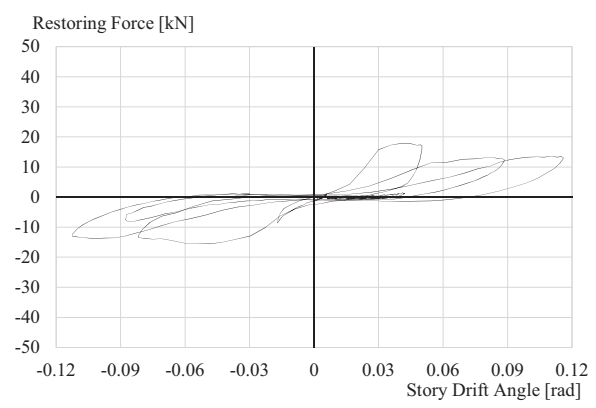

PLY4-specimen

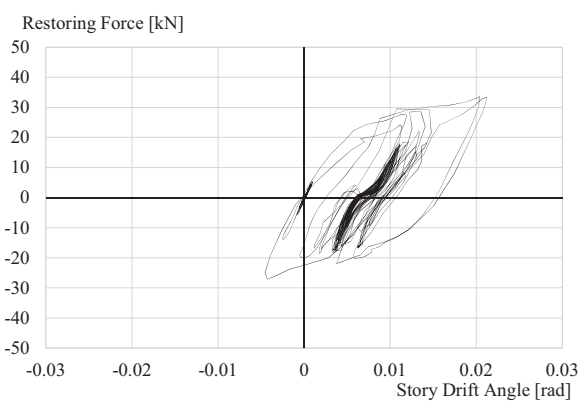

SF4-specimen

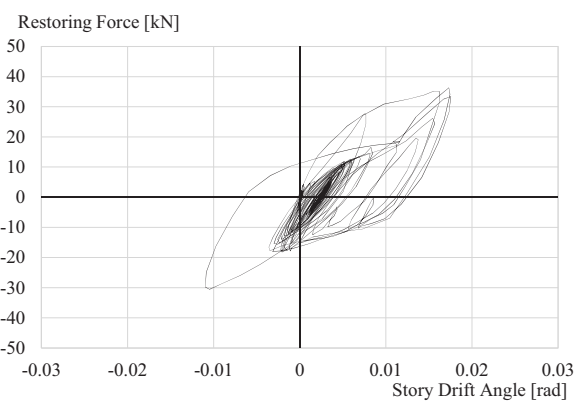

PLY+SF-specimen

(a) JMA-Kobe (1

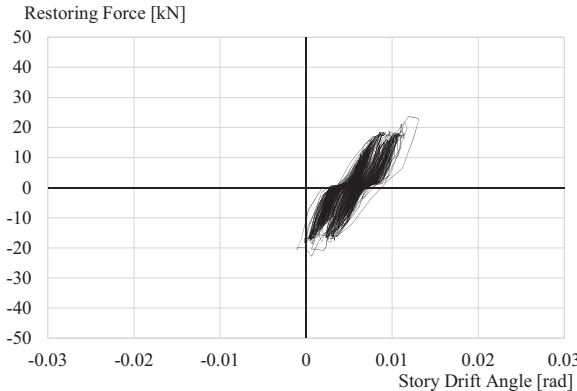

SF4-specimen

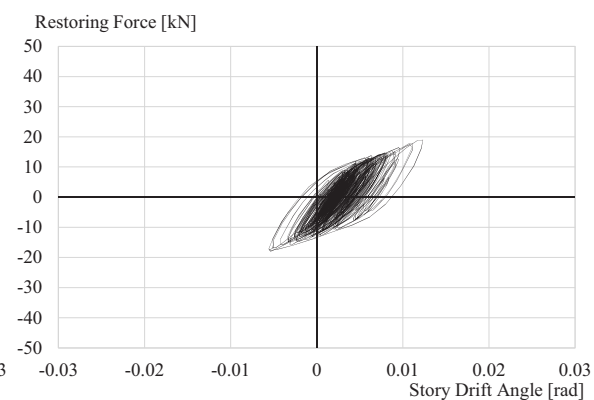

PLY+SF-specimen

(b) BCJ-L2

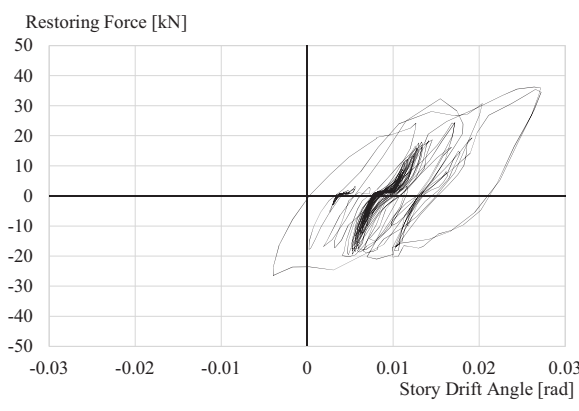

SF4-specimen

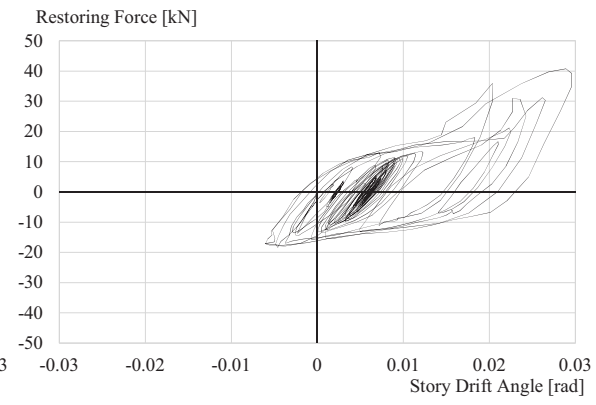

PLY+SF-specimen

(c) JMA-Kobe(2)

Fig. 9 Test Results of Hysteresis Loops of Restoring Force - Story Drift 


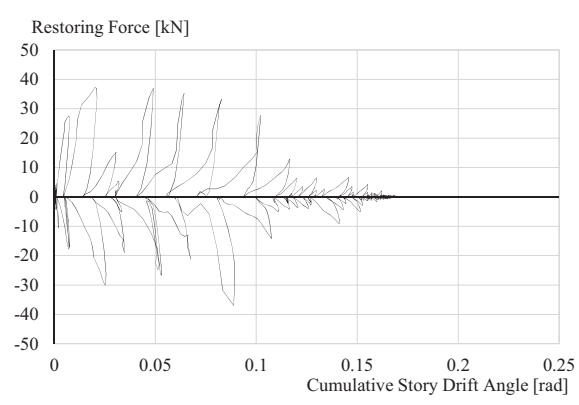

PLY4-specimen

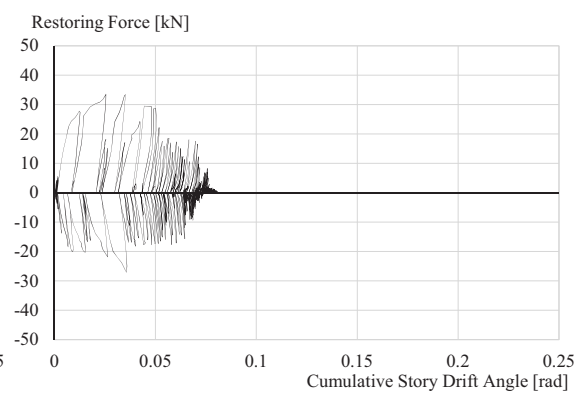

SF4-specimen

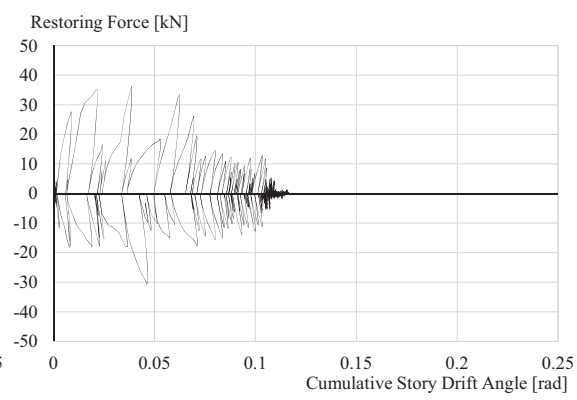

PLY+SF-specimen

(a) JMA-Kobe 1

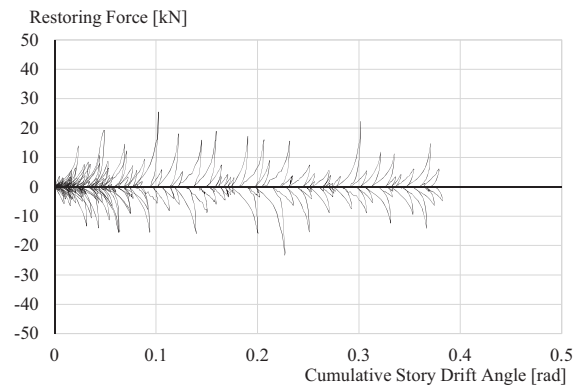

PLY4-specimen

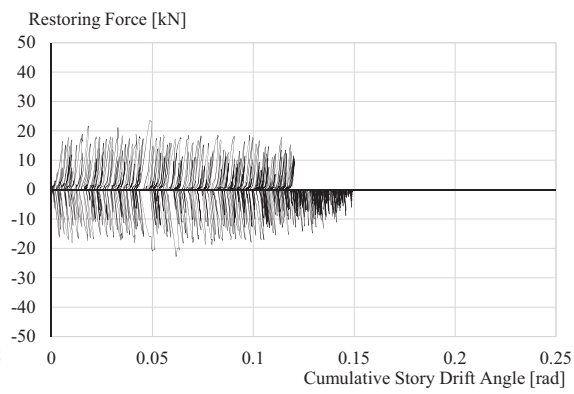

SF4-specimen

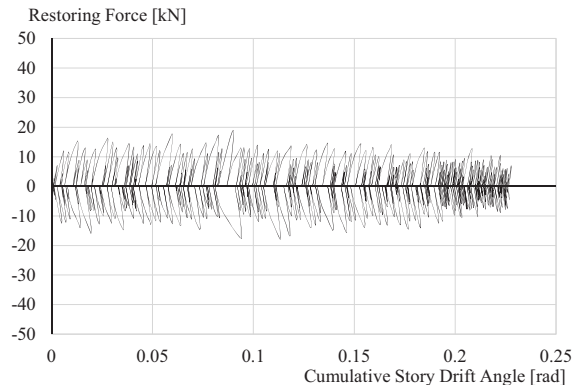

PLY+SF-specimen

(b) BCJ-L2

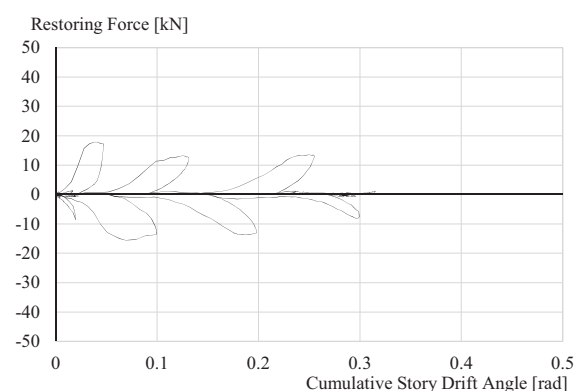

PLY4-specimen

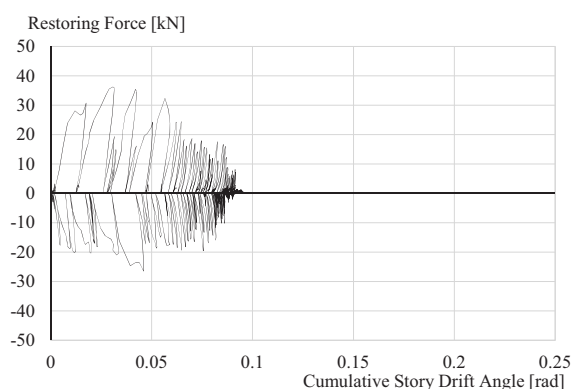

SF4-specimen

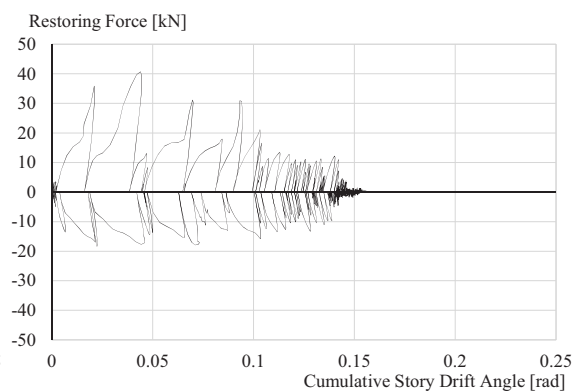

PLY+SF-specimen

(c) JMA-Kobe(2

Fig. 10 Cumulative Story Drift Curve of Test Results

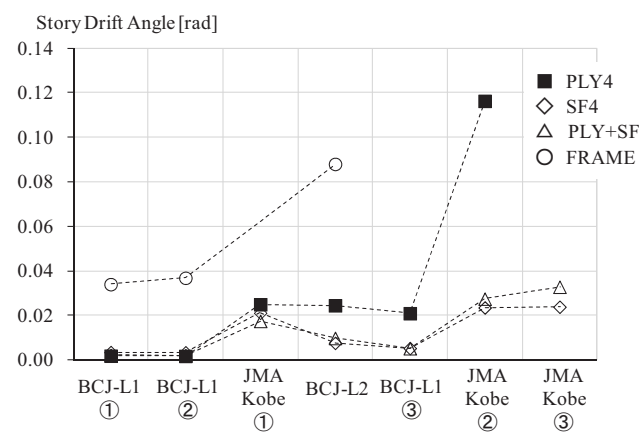

Fig. 11 Transition of Maximum Story Drift

わゆる合板が損傷した際に見られるスリップ挙動とは異なるもので ある。ここで, PLY+SF 試験体に関して, Figs.9 (a), 10 (a)の JMA-Kobe (1)入力時の結果より, 入力初期で高い荷重を示し, その後荷重が低 下しているが，紡鍾型の履歴挙動を示していることが確認できる.
さらに, JMA-Kobe(1)の後で弾塑性応答挙動を示した BCJ-L2 入力に よる Figs.9 (b), 10 (b)の結果より, 荷重が小さくなっていることが確 認できる，これらの比較より，地震動の前半で合板が損傷して荷重 が低下したものの，SFDによる耐荷機構により安定した履歴曲線を 示したと考えられる.

以上より，PLY+SF の試験体において，合板が損傷するとスリッ プ挙動を呈し, 耐力が低下寸るが, SFD が耐荷要素として抵抗し, 合板が損傷した後も安定した復元力特性を示すことが確認できる. このことから, 終局状態において SFD が耐荷要素として有効に機能 していることが考えられる.なお, SFD を有する試験体では, JMA-Kobe(1)以降に残留変形が生じ, JMA-Kobe(3)入力後の終局状態 では大きな残留変形が生じるが，2 度の終局状態の入力を経験して も, SFD の復元力特性により, 倒壊に至るような甚大な損傷は防止 できている.さらに, PLY4 試験体と比較して, 初期の入力から終 局状態に至るまでの応答を低減し，PLY+SF 試験体では，合板の損 
傷を抑制する効果が確認できる.

著者らは，耐震部材（合板）と制振部材（SFD）を有する PLY+SF の組合せを標準と考えている. SFDの効果として, 地震入力の小さ な範囲では合板の損傷を抑制し, 地震入力の大きな範囲では建物全 体の甚大な被害を抑制する性能を有しているものと判断される.

\subsubsection{SFDのエネルギ一吸収量}

Fgi.12の結果より，SF4 試験体では，SFD が負担するエネルギー 吸収量は，終局入力レベルまで $80 \%$ 前後で安定した值を示している ことが確認できる。しかし，PLY+SF 試験体は，合板が損傷する BCJ-L2 入力前では, 合板の寄与が大きく SFD の負担は $30 \%$ 程度で あったが，JMA-Kobe(1)により合板が損傷した後は SFD の寄与が増 し，70\%前後と負担が大きくなっている．以上より，合板と SFDを 併用することで, 合板が損傷した後も SFD が而荷要素として機能し ていることが確認できる.

\subsection{4 等価粘性減衰定数と制振効果}

Fig.13 より, SF4 試験体と PLY+SF 試験体では, 層間変形角の増 加に伴い, 等価粘性減衰定数も増加寸る傾向が確認できる.このこ とから, SFD を用いた試験体は, 塑性化後も安定した制振効果が期 待できる。これに対して, PLY4 試験体では, 層間変形角の増加に 伴う等価粘性減衰定数の増加は見られず, JMA-Kobe(1)入力時に発生 した合板の釘のせん断損傷により，その後の地震波入力時にスリッ プ挙動が表れ，JMA-Kobe(2)入力時において層間変形角が増大した。

\section{5. 地震応答解析による終局耐震挙動の検討}

\section{1 地震応答解析の概要}

前章では，実験結果より各試験体の復元力特性や終局耐震性能，

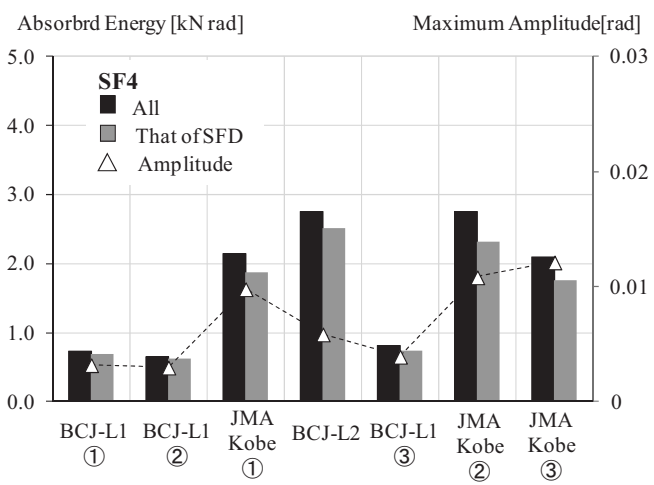

(a) SF4-specimen

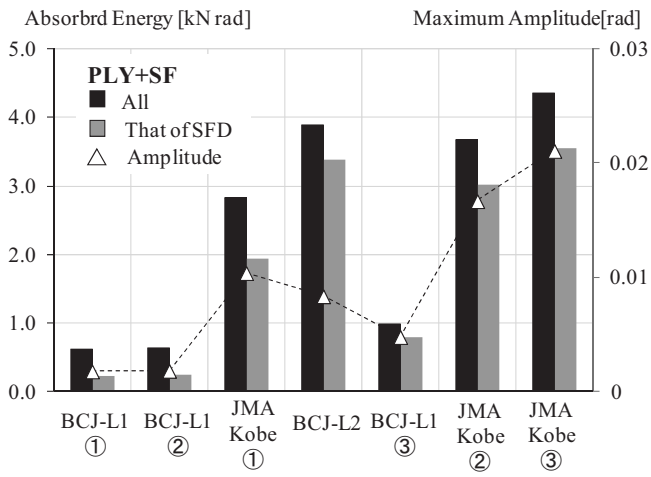

(b) $\mathrm{PLY}+\mathrm{SF}-$ specimen

Fig. 12 Energy Absorption of SF and Frame
制振構造としての SFD の効果を検討した．特に，復元力特性は，実 験で観察された試験体の耐荷要素の損傷状況と対応しており，妥当 なものと考えられる. 本章では, SFDを有する木質軸組架構に対し, 地震応答解析による追跡精度の検討を行い, 地震応答解析手法の適 用性や有効性を検討する。これにより，実験で観察された崩壊モー ドや弾塑性挙動の主たる耐荷要素や復元力特性を検討し, 終局動的 挙動に関する解析的検討を試みる.

\section{2 解析モデルと解析条件}

前章の実験結果より, 本稿の試験体は, 主として構造用合板, SFD が水平耐荷要素として機能しており，振動台実験ではその代表的な 復元力特性が確認された。そこで，既往論文 ${ }^{11)}$ に基づき，実験結果 より各耐荷要素の復元力特性をモデル化する.

各試験体の実験結果の包絡曲線を抽出し, 加算則により各耐荷要 素の骨格曲線を求め, Fig.14 に示す. 実験結果より求めた各耐荷要 素の骨格曲線より, 復元力モデルとして SFD は Tri-linear 型, 合板

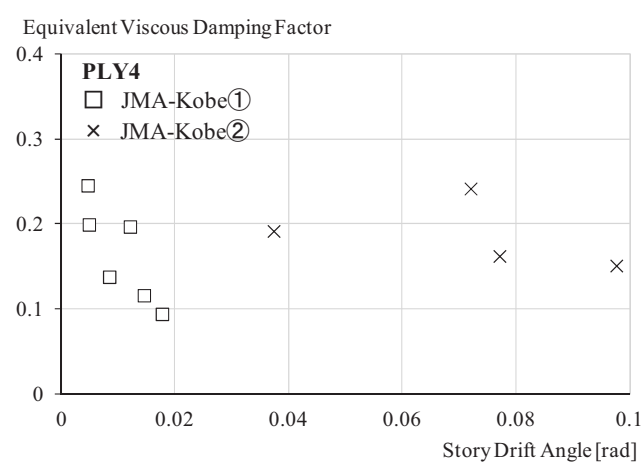

(a) PLY4-specimen

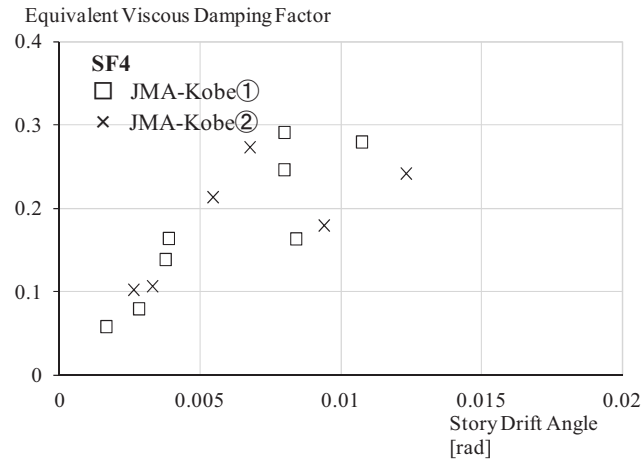

(b) SF4-specimen

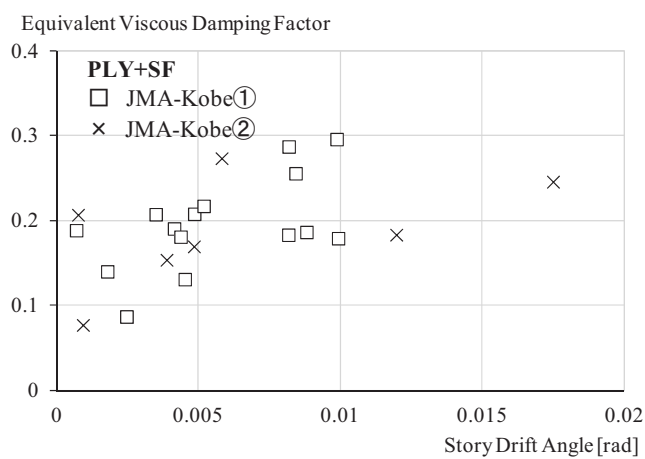

(c) PLY+SF-specimen

Fig. 13 Test Results of Equivalent Viscous Damping Factor 
と軸組は Bilinear 型とする. なお, 合板の骨格曲線の耐力劣化域は, 最大耐力の $50 \%$ に達するまでとする. また, 各耐荷要素の履歴則と して, SFDはスケルトン・シフトモデル ${ }^{12)}$, 合板と軸組は Bilinear+Slip モデル 13)を採用する.

振動解析モデルは, 以上の復元力特性モデルの並列系による 1 質 点系とした. 地震応答解析の積分法は平均加速度法, 時間刻み 0.01 秒とし, 減衰定数は $2 \%$ とした。

\section{3 解析結果と考察}

地震応答解析を行い, 一例として JMA-Kobe(1), JMA-Kobe(2)の解 析結果を Fig.15 に示す.ささらに, 実験では検出・分離が困難であっ た SFD と構造用合板のそれぞれの弾塑性挙動を, 解析結果より求め, 一例として JMA-Kobe11)の結果を Fig.16 に示す. なお, JMA-Kobe (2)において, PLY4 試験体の応答解析では, 最大耐力から $50 \%$ 以上 低下したため, 参考として応答解析の途中までの結果を示している.

Fig.9 と Fig.15の比較より, スリップ性状に差があるものの, 各試 験体の応答振幅や履歴挙動を精度良く追跡できていることが確認で きる. さらに, Fig.16の解析結果より, PLY+SF 試験体では, 合板 の損傷によるスリップ性状が顕著に表れているが，SFDによる紡錘 型の挙動により, 全体として安定した履歴挙動を示している.なお, 残留変形については, 実験結果の傾向を追跡できていないが, 本稿 では, SFDの効果に関して, 主として最大応答や弾塑性挙動の追跡 性を検証することを目的としている.

以上より, 各耐荷要素の復元力特性と履歴則は, 木質構造ならび に鉄骨構造の解析モデルを用いることで, 実験結果を追跡すること
ができる.さらに, 実験結果の弾塑性挙動, 寸なわち合板のスリッ プとピンチング, SFDの紡錘型の履歴挙動は, 解析結果と対応して おり，解析手法が妥当であることが確認できる。 また，PLY+SF 試 験体では，合板が損傷した後も安定した履歴曲線を示したが，これ はSFD の高い塑性変形能力によるものであることが確認された。

\section{4 等価粘性減衰定数に関する解析的検討}

地震応答解析結果から, 等価粘性減衰定数を求めた。一例として JMA-Kobe(1)，JMA-Kobe(2)の解析結果を Fig.17 に示す.また, この 解析結果において, 各応答振幅から等価粘性減衰定数を算出し, 層 間変形角との関係を Fig.17 に併せて示寸.

Fig.13と Fig.17より, 実験結果と解析結果は概初対応しているこ とが確認できる。これより，SFDを有する木質架構の等価粘性減衰

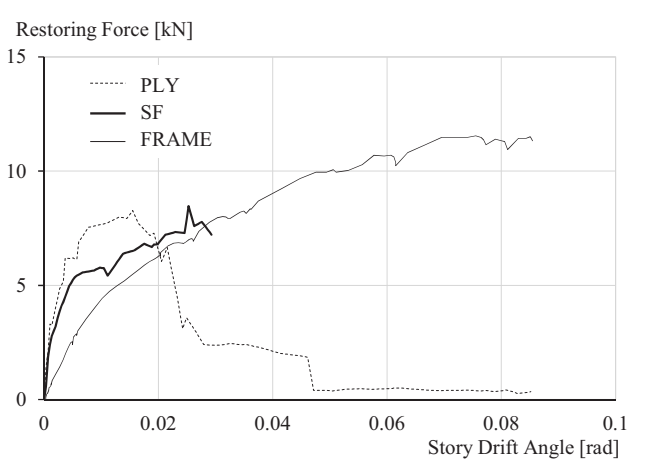

Fig. 14 Skelton Curve Model of Each Resistant Members

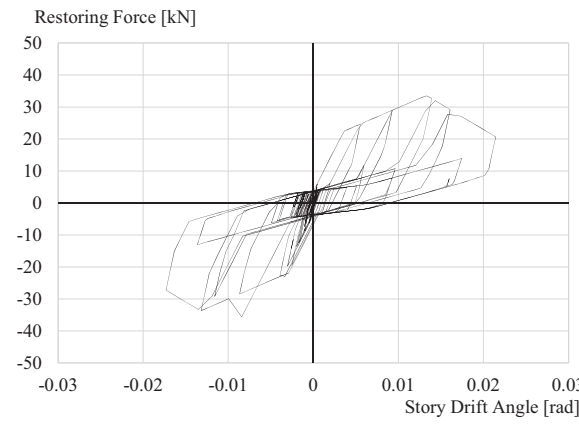

PLY4-specimen

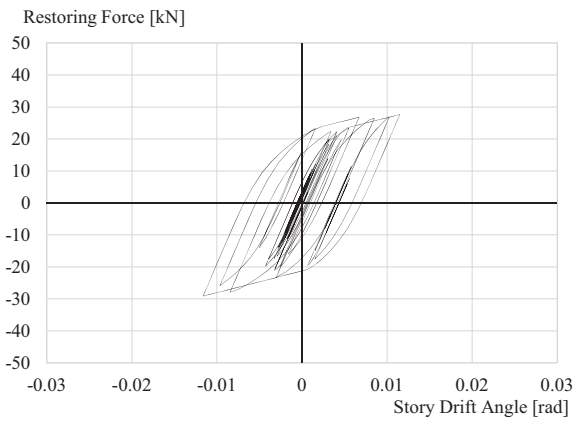

SF4-specimen

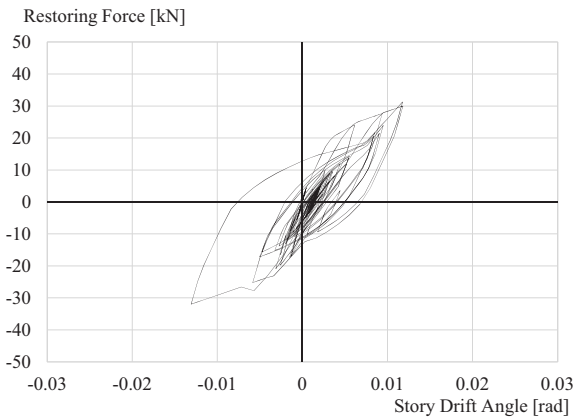

PLY+SF-specimen

(a) JMA-Kobe 1

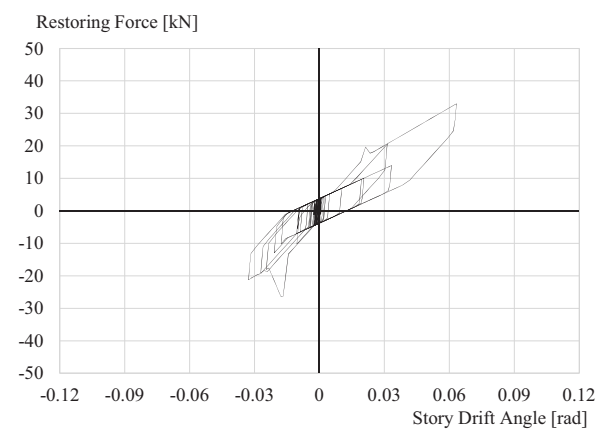

PLY4-specimen

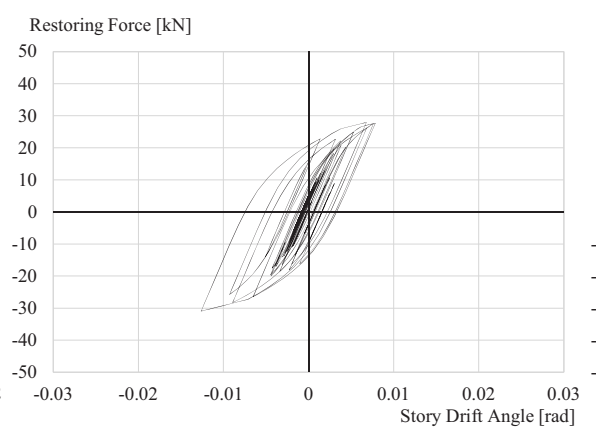

SF4-specimen

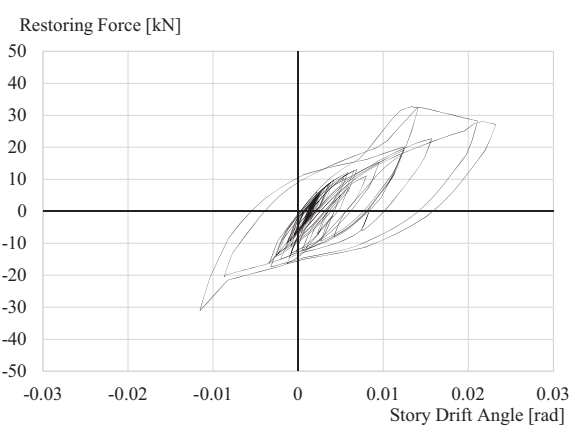

PLY+SF-specimen

(b) JMA-Kobe(2)

Fig. 15 Analytical Results of Hysteresis Curve 


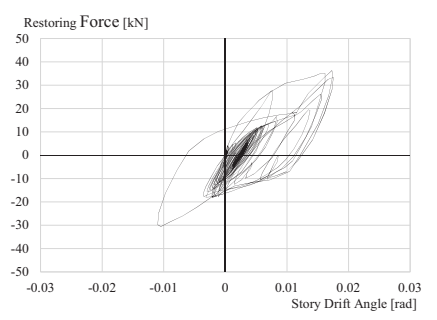

Test Results

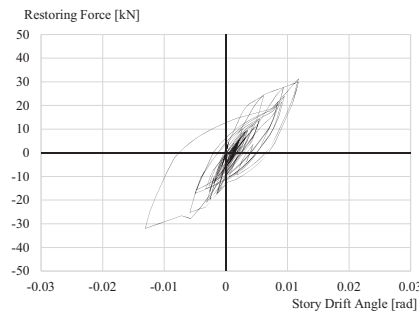

Al I

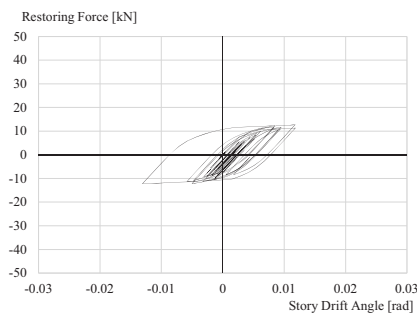

SF

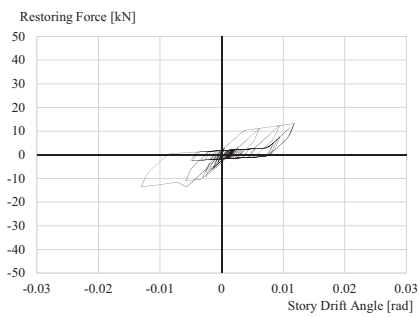

PLY

Analysis Results

(a) PLY+SF-specimen (JMA-Kobe(1)

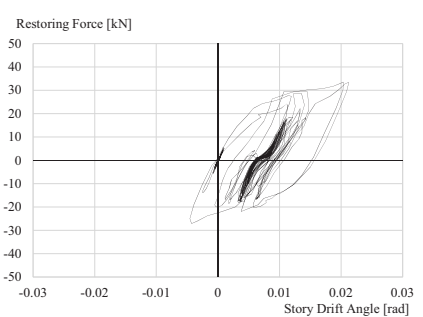

Test Results

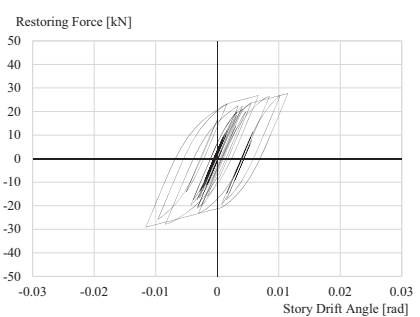

Al I

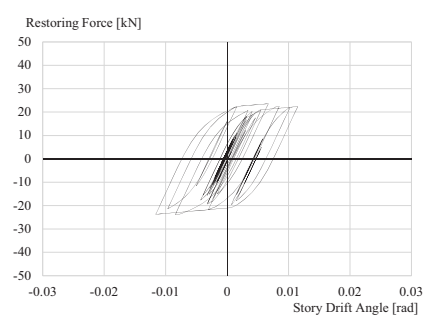

SF

Analysis Results
(b) SF4-specimen (JMA-Kobe(1))

Fig. 16 Comparison of Restoring Force Behavior of Each Resistant Member

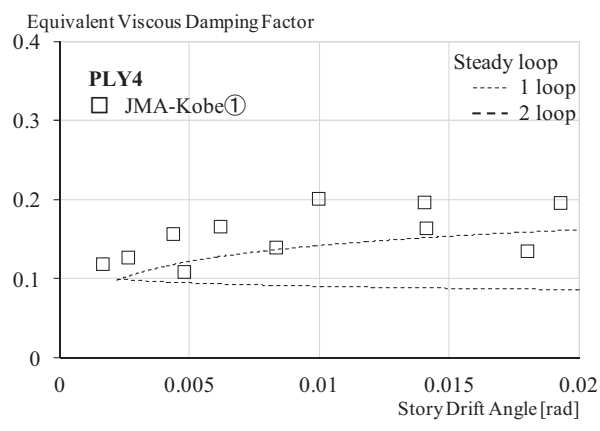

(a) PLY4-specimen

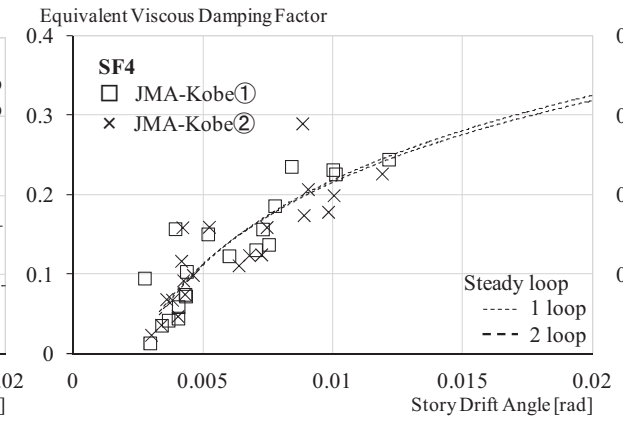

(b) SF4-specimen

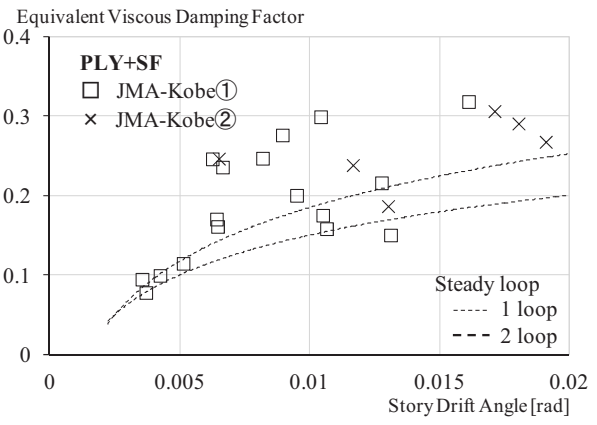

(c) PLY+SF-specimen

Fig. 17 Analytical Results of Equivalent Viscous Damping Factor

は, 本稿の解析法, 寸なわち合板と SFD の復元力特性モデルにより, 評価することが可能であると考えられる.

\section{6. 結び}

本研究では, 金属系材料による曲げ抵抗系の履歴型の制振ダンパ 一を提案し, 木質架構に設置した制振構造を対象にして, 振動台実 験を実施した。実験結果の分析を行い, 終局耐震挙動時の耐荷機構 や復元力特性を明らかにし, 振動特性についても検討した.さらに, 地震応答解析を行い, 実験結果の追跡精度や耐荷要素について検討 を行った.

本稿の検討により, 以下のことを確認した.

1. 実験結果より求めた固有周期より, 試験体に損傷が生じる前の 固有周期は，試験体設計時に想定した固有周期と概ね一致いた. その後, 試験体に損傷が生じると固有周期が変化し, 特に, 構 造用合板が損傷した試験体では剛性の低下により, 固有周期が
大きくなった，一方，SFD を有する試験体では，終局レベルに 至るまで, 固有周期は大幅に上昇することなく, SFD が抵抗要 素として機能していた。

2. 弾塑性挙動と復元力特性の検討より, 構造用合板のみを有する 試験体では，合板の損傷によりスリップ挙動を示すが，SFDを 有する試験体では, 終局レベルにおいても紡錘型の履歴挙動を 示す．なお，SFD と構造用合板を併用した試験体では，構造用 合板の損傷によりピンチングや耐力低下が確認されるものの, 履歴挙動としては紡錘型を示す.

3. SFD と試験体全体の塑性吸収エネルギーを求めた. SF4 試験体 では, 終局レベルまで SFD が負担するエネルギー吸収量は $80 \%$ 前後で，安定した值を示した。PLY+SF 試験体は，合板が損傷 寸る BCJ-L2 入力前では，合板の寄与も大きく SFD の負担は 30\%程度であったが，JMA-Kobe11により合板が損傷した後は SFD の寄与が増し， 70\%前後と負担が大きくなった． 
さらに，本稿の検討により，以下の結論を得た。

4. 実験結果より, 各試験体の等価粘性減衰定数を求めた. SFD を 有する試験体では，層間変形角の増加に伴い，等価粘性減衰定 数が増加する傾向を示す。このことから, SFD を用いた試験体 は，塑性化後も制振効果が期待できる.

5.さらに, SFD を有する木質軸組架構に対して地震応答解析を行 った。実験結果との比較により，この解析手法により実験結果 の弾塑性挙動を追跡できることを示した.さらに, 解析結果よ り各耐荷要素の弾塑性挙動を抽出し, 弾塑性挙動について解析 的検討を行った. 結果として, 構造用合板が損傷後の SFD の 有効性が示された。

6. 解析モデルに基づき等価粘性減衰定数を求め, 解析結果は実験 結果と概ね対応していることを示した。これより，SFDを有す る木質架構の等価粘性減衰は, 合板と SFD の復元力特性モデ ルにより，評価することが可能である.

\section{謝辞}

本研究の振動台実験は，UR 都市機構技術研究所にて実施し，関 係者より多大なご助言とご協力を得ました。また，谷慎一朗君，島 田誓也君, 高橋武大君, 府川直人君 (本学・元大学院生), 阿津英明 君, 北朴木茉奈さん, 島田稜子さん（本学大学院生）に振動台実験 のご協力を得ました。ここに記して謝意を表します.

\section{補遺 $A: S F$ 構造の水平剛性と耐力}

SF構造が水平力を受けると，SFDはFig.1のような応力分布になる。この曲 げモーメント図に基づき, 仮想仕事法の原理より水平剛性と降伏時耐力は次 式で表される.

水平剛性 : $\mathrm{K}_{\mathrm{SF}}=\frac{12 \mathrm{E} \mathrm{I}_{\mathrm{SF}} \mathrm{L}^{2} \cos ^{2} \theta}{\alpha^{3} \mathrm{~B}^{2} \mathrm{H}^{2}(\mathrm{~B}+\mathrm{H})}$

降伏時耐力: $\mathrm{P}_{y}=\frac{4 \mathrm{f}_{\mathrm{b}} \mathrm{Z}_{\mathrm{SF}}}{\alpha \mathrm{H}}$

ここで，E， $\mathrm{IFF}_{\mathrm{SF}}, \mathrm{Z}_{\mathrm{SF}}, \mathrm{f}_{\mathrm{b}}$ : SFDのヤング係数，断面2次モーメント，断面係数， 曲げ降伏応力度, B, H, L : 柱梁フレームの幅, 高さ, 対角線長さ, である.

\section{補遺B：SF構造の斜材軸力}

$\mathrm{SF}$ 構造の水平載荷試験結果 ${ }^{4)}$ における斜材軸力と層間変位の関係を Fig.B-1 に示す.これより, 小変形領域では SF の伸び側と短縮側の斜材軸力はほぼ等 しいが, 大変形領域において短縮側の斜材軸力が低下寸る様子が確認できる. さらに, 本実験における各加振波の最大応答時の斜材ひずみを Fig.B-2 に示 す。これより，大変形領域において，短縮側の斜材軸力が低下していること が確認できる.
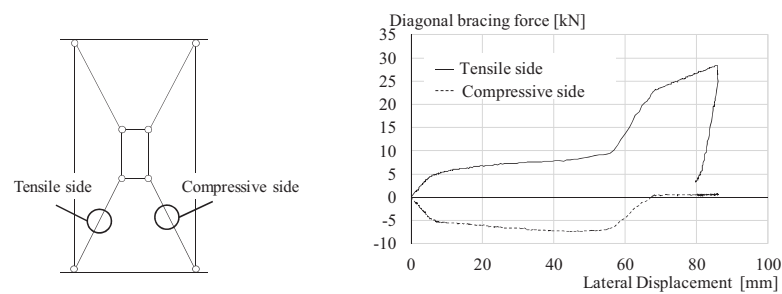

Fig. B-1 Relation of axial force - story drift of diagonal brace ${ }^{4}$

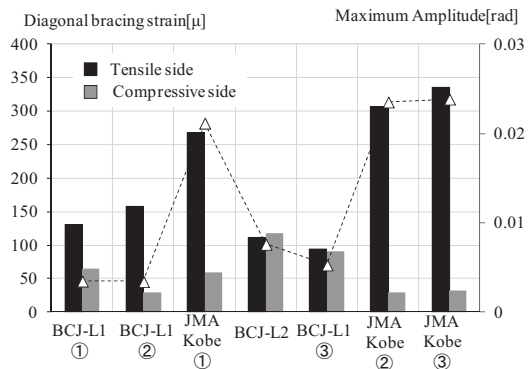

Fig. B-2 Maximum axial force of diagonal brace under shaking test

参考文献

1) パッシブ制振構造 設計・施工マニュアル第 3 版, 日本免震構造協会, 2007.7

2) 呉東航編著:「よくわかる住まいの耐震・制振工法」住まいの学校 2012.12

3) 伊藤拓海ほか：スケーリング・フレーム構造を有するツーバイフォー工 法による木造制振架構の水平載荷試験, 日本建築学会関東支部研究報告 集 I , pp.353-356, 2016.3

4) 齋藤真美，谷槙一朗，伊藤拓海，吳東航：スケーリング・フレーム構造 の鉄骨構造物一の適用性と制振効果に関寸る研究 その 1 , 日本建築学 会関東支部研究報告集 I, pp.529-532，2014.2

5）齋藤真美，伊藤拓海ほか：スケーリング・フレーム構造の鉄骨構造物へ の適用性と制振効果に関する研究 その 2 , 日本建築学会大会学術講演 梗概集，構造III，pp.1189-1190，2014.9

6)阿津英明，島田誓也，伊藤拓海ほか：スケーリング・フレーム構造の鉄 骨構造物一の適用性と制振効果に関する研究 その 3 , 日本建築学会関 東支部研究報告集 I ，pp.525-528，2015.3

7）山口界堂ほか：スケーリング・フレーム構造の鉄骨構造物への適用性と 制振効果に関する研究 その 4 ，日本建築学会関東支部研究報告集 I, pp.433-436, 2016.3

8）小原勝彦，宮澤健二：実大振動実験における履歷特性に関する研究，構 造工学論文集, vol.47B, pp.341-348, 2001.3

9) 穴吹拓也，佐野剛志ほか：縮小 20 層 $\mathrm{RC}$ 造建物試験体の長周期地震動に よる震動実験 その 4 各層の応答性状, 日本建築学会大会学術講演梗 概集，構造IV，pp.673-674，2013.8

10）梅森浩，馬場章子ほか：実大振動台実験に基づく木質系耐力壁構造の耐 震性能に関する研究，構造工学論文集，vol.55B，pp.171-178，2009.3

11) 佐藤利昭，肥田剛典，加藤惊ほか：木造住宅用制振装置の性能評価一振 動台実験による加算則の検証と動特性評価一，日本建築学会技術報告集， 第 45 号, pp.539-544，2014.6

12) 白井佑樹, 下田裕介，伊藤拓海：繰返し載荷を受ける $\mathrm{H}$ 形鋼梁の耐力と 変形能力のデータベース その 3 , 日本建築学会関東支部研究報告集 I, pp.109-112, 2011.2

13) 荒木康弘, 腰原幹雄, 大橋好光, 坂本功: 木造住宅の地震応答解析のた めの復元力モデルに関する研究，日本建築学会構造系論文集，No.579, pp.79-85, 2004.5 


\title{
SHAKING TABLE TEST AND ULTIMATE SEISMIC BEHAVIOR \\ ON PASSIVE CONTROLLED WOODEN FRAME
}

\author{
Takumi ITO*, Kurumi KUROKAWA **, Dong Hand WU***, \\ Takashi NAGUMO **** and Haruhiko HIRATA ***** \\ * Assoc. Prof., Dept. of Archi., Faculty of Eng., Tokyo Univ. of Science, Dr.Eng \\ ** Grad. Stud., Dept. of Archi., Graduate School of Eng., Tokyo Univ. of Science, B.Eng. \\ ** President, WU Building Office Corp., Dr.Eng. \\ **** Development Division General Manager, Hory Corporation \\ ***** Structure Equipment Sales Department, Hory Corpotation
}

A various type of seismic passive control system has been developed on many countries with frequent earthquakes. And also, these are categorized from the viewpoint of structural system, resistant mechanism, material, etc. as shown Tables 1, 2. Herein, a new passive control system called Scaling Frame (abbreviated SF) has been suggested as shown in Fig.1. In our previous studies of SF structures, the fundamental resistant characteristics are investigated experimentally as shown in Fig.2, and the analytical method of SF structures which is adopted on steel frames has been proposed.

In this study, the ultimate seismic response behavior and response mitigation effects of SF on wooden structures are investigated by shaking table tests on one-story wooden framed test specimen. Herein, four test specimens of various structural types are prepared with SF and structural plywood installed as shown in Fig.3 (a), (b). And the input wave are assumed as follows; 1) foreshocks to investigate the standard seismic performance, 2) main shocks to estimate the ultimate seismic response behavior, 3) aftershocks to analyze the fail-safe mechanism of SF structures, and 4) mega earthquake input to study the ultimate limit state of test frame specimens.

From the test results (Figs.9, 10, 11, 12), the following behaviors are observed;

In case of test specimen which consists of plywood only, the slip behavior and deterioration of restoring force are generated (see Figs.9, 10). And also, the response story drift becomes large after main shocks input because the plywood does not resist.

On the other hands, in case of test specimen with SFD installed, the stable hysteresis loop is observed (see Figs.9, 10). And the residual restoring force is obtained after main shocks input. Furthermore, it is observed that good plastic energy absorption of SFD is presented during ultimate seismic response (see Figs.9, 10).

From these observations, SFD has good seismic resistant performance from the point of seismic mitigation effects and plastic energy absorption. Furthermore, SFD becomes fail-safe element after the plywood is experienced under severe damage.

The equivalent viscous damping factor is calculated from the test results, and it is clarified that the SF structure has high damping factor during ultimate state (see Fig.13).

Next, the analytical studies are performed to investigate the ultimate seismic response behavior and the accuracy of dynamic response analytical method. The skeleton curves of each member (frame, plywood and SFD) are extracted from the envelop curves of test results (see Fig.14). And from the observation of test results, each restoring force characteristics model can be summed from the summation rule. The response analysis is performed, and the results are compared with test results, the accuracy of analysis method is concerned (see Figs.9, 15). And also, the fail-safe mechanism during seismic response is presented analytically (see Fig.16).

Finally, the analytical results of equivalent viscous damping factor are calculated by use of above analytical method. From the comparison analytical results and test results (see Figs.13, 17), it shows good agreement with each other.

So then, the main conclusions of this paper are as follows: The specimen by use of only plywood shows the slip on hysteresis loop and the larger response displacement because of damage of plywood. However, the specimens with SF device installed don't show the above results after even plywood damage. Therefore, installing SF device shows equable hysteretic behavior, and mitigation effects of SF structure after plywood does not function as seismic resistant element during ultimate state. And also, the accuracy of response analysis method can be presented. 